\title{
A new species of the armored catfish genus Pareiorhaphis Miranda Ribeiro (Siluriformes: Loricariidae) from the rio Paraguaçu, Bahia State, northeastern Brazil
}

\author{
Edson H. L. Pereira ${ }^{1}$ and Angela M. Zanata ${ }^{2}$
}

A new armored catfish species of the genus Pareiorhaphis is described from the middle and upper portions of rio Paraguaçu basin, coastal drainage of Bahia State, northeastern Brazil. The new species is readily distinguished from all its congeners by having two putative autapomorphies: (1) skin fold just posterior to each emergent tooth series of dentary formed by a single enlarged, flattened papilla, and (2) the midline of lower lip immediately behind the dentaries with small patch of distinct papillae arranged in a short median bump. In addition, the shallow caudal peduncle and comparatively lower number of teeth in each dentary also distinguishes the new species from all congeners. The new species is also compared to Pareiorhaphis bahianus, the geographically closest congener.

Uma espécie nova de cascudo do gênero Pareiorhaphis é descrita da porção média e superior da bacia do rio Paraguaçu, drenagem costeira do estado da Bahia, nordeste do Brasil. A espécie nova é facilmente diagnosticada das demais congêneres por apresentar duas possíveis autapomorfias: (1) uma prega de pele atrás de cada série emergente de dentes do dentário formada por uma única papila larga e achatada e (2) um conjunto de papilas distintas arranjadas em uma elevação curta localizada na linha média do lábio inferior. Além disso, a menor altura do pedúnculo caudal e o baixo número de dentes em cada dentário também distinguem a espécie nova de todas as congêneres. A espécie nova é ainda comparada com Pareiorhaphis bahianus, congênere geograficamente mais próximo.

Key words: Cascudos, Chapada Diamantina, Neoplecostominae, Neoplecostomus, Pareiorhaphis bahianus.

\section{Introduction}

Pareiorhaphis Miranda Ribeiro currently comprises 21 nominal valid species of small to medium-sized suckermouth armored catfishes easily recognized by a series of derived features, including cheeks, opercle, and the exposed lateral process of the cleithrum of adult males covered with hypertrophied odontodes, and the lateroventral portion of preopercle deeply rugose due to the attachment of hypertrophied odontodes (Pereira et al., 2007, 2010). Species of Pareiorhaphis are almost completely restricted to rivers draining the Brazilian Shield, with the exception of P. regani (Giltay), which was described from a tributary of the rio Negro, in the Amazon basin. Although the highest species diversity of the genus has been traditionally attributed to southern drainages, with at least nine species occurring in Santa Catarina State, in the last two decades six new species were revealed to occur in rivers draining a more northeastern portion of the country (e.g., rio Doce, rio Jequitinhonha, and rio São Francisco drainages), and two small coastal rivers of the Espírito Santo State, named Piraquê-Açu and Reis Magos. Up to date, P. bahianus (Gosline) described from Fazenda Almada, Ilhéus, is the only species known to occur in Bahia State and represents the northernmost distribution record of the genus. The type locality of $P$. bahianus is within the area drained by the rio Almada and this species is recorded from various small coastal rivers located between the rio Pardo and rio de Contas basins (Carvalho \& Bockmann, 2007).

Field expeditions over the last eight years in coastal drainages of Bahia State yielded several undescribed species

${ }^{1}$ Laboratório de Sistemática de Vertebrados, Pontifícia Universidade Católica do Rio Grande do Sul. Av. Ipiranga, 6681, P. O. Box 1429, 90619-900 Porto Alegre, RS, Brazil. ehlpereira@gmail.com

${ }^{2}$ Departamento de Zoologia, Instituto de Biologia, Universidade Federal da Bahia. Rua Barão de Geremoabo, s/n, Ondina, 40170-290

Salvador, BA, Brazil. zanata.angela@gmail.com 
of armored catfishes, revealing an unknown diversity of loricariids in the area. This fact can be exemplified by discoveries of two new species of Hypostomus describe recently (Birindelli et al., 2007; Zanata et al., 2013) and a new species of Pareiorhaphis described herein.

\section{Material and Methods}

All morphometric features were taken as pointto-point linear distances with digital calipers under a stereomicroscope, and recorded to the nearest $0.1 \mathrm{~mm}$. Counts and measurements followed Pereira et al. (2007). Nomenclature and counts of body plates follow Schaefer (1997). Standard length (SL) is expressed in millimeters while all other measurements are given as percents of SL, except for subunits of the head, which are presented as percents of the head length (HL). Counts of procurrent caudal-fin rays and vertebrae were made only in cleared and counterstained specimens (c\&s) prepared according to Taylor \& Van Dyke (1985). Vertebral counts comprise all vertebrae including the five centra modified into the Weberian apparatus and the compound caudal centrum (PU1+U1) was counted as one element. Meristic and morphometric data for comparisons of Pareiorhaphis species in the diagnosis section are from Pereira \& Reis (2002), Pereira (2005), Pereira et al. (2007, 2010), Pereira \& Britto (2012), and Pereira et al. (2012). Institutional abbreviations are: Museu de Ciências e Tecnologia, Pontifícia Universidade Católica do Rio Grande do Sul, Porto Alegre (MCP); Museu de Zoologia, Universidade de São Paulo, São Paulo (MZUSP); and Universidade Federal da Bahia, Salvador (UFBA). Descriptions of coloration were based on specimens preserved in ethanol and photographs of the freshly collected specimens. In the lists of examined material the museum abbreviation and catalog number come first, followed by the number and SL range of specimens in that lot, the number and SL range of specimens measured for the morphometric comparisons, in parentheses, and locality.

Adult males of Pareiorhaphis are herein defined according to Pereira et al. (2007). The specimens included in the list of material examined are a combination of male, female and immature specimens of both sexes.

\section{Results}

\section{Pareiorhaphis lophia, new species Figs. 1-3}

Holotype. MCP 47711, 76.9 mm SL, male, Brazil, Bahia State, Lençóis, rio Paraguaçu drainage, rio Santo Antônio at bridge on road BR-242, 12²9’37’'S 41¹9’38”W, 350 m above sea level, 7 Jul 2011, A. M. Zanata, P. Camelier, J. Birindelli, R. Burger \& B. Sardeiro.
Paratypes. All from Brazil, Bahia State, rio Paraguaçu basin. MCP 47712, 18, 30.1-82.1 mm SL (6, 63.1-82.1 mm SL), 1 c\&s, $64.1 \mathrm{~mm}$ SL, and UFBA 7063, 25, 31.0-71.8 $\mathrm{mm} \mathrm{SL}(3,66.5-71.8 \mathrm{~mm} \mathrm{SL})$, collected with the holotype. MCP 48004, 3, 72.6-81.8 mm SL, 1 c\&s, $72.6 \mathrm{~mm}$ SL, rio Paraguaçu at Fazenda Os Touros, ca. $18 \mathrm{~km}$ from Iaçu, $12^{\circ} 41^{\prime} 10^{\prime \prime}$ S 407'47”W, 143 m a.s.l., Sep 2011, J. J. S. Conceição. MZUSP 86089, 3, 45.5-57.8 mm SL, rio Paraguaçu, upstream Itaetê, $12^{\circ} 58^{\prime} 25^{\prime \prime S} 40^{\circ} 58^{\prime} 20^{\prime \prime} \mathrm{W}, 21$ Sep 2004, M. E. Bichuette et al. MZUSP $86154,1,62.8 \mathrm{~mm}$ SL, rio Paraguaçu, upstream Itaetê, $12^{\circ} 58^{\prime} 25^{\prime} \mathrm{S}$ $40^{\circ} 58^{\prime} 20^{\prime \prime}$ W, 8 Nov 2004, M. E. Bichuette \& F. D. Passos. MZUSP 88163, 10, 54.8-71.4 mm SL; UFBA 7026, 5, 54.2-62.5 mm SL, rio Paraguaçu at Fazenda Os Touros, ca.18 km from Iaçu, $12^{\circ} 41^{\prime} 10^{\prime \prime} \mathrm{S}$ $40^{\circ} 7^{\prime} 47^{\prime \prime} \mathrm{W}, 143 \mathrm{~m}$ a.s.l., 8 Jun 2005, A. M. Zanata, J. L. O. Birindelli, O. T. Oyakawa, M. P. Geraldes, P. Camelier \& P. Moura. UFBA 6188, 1, $79.3 \mathrm{~mm} \mathrm{SL}$, rio Paraguaçu at Fazenda Os Touros, ca. $18 \mathrm{~km}$ from Iaçu, $12^{\circ} 41^{\prime} 10^{\prime \prime}$ S 407'47”W, 15 May 2010, A. M. Zanata, R. Burger, C. Primitivo, D. França \& J. J. S. Conceição. UFBA 7350, 6, 30.580.9, rio Una at Cachoeira das Andorinhas, Iramaia, $13^{\circ} 19^{\prime} 52.5^{\prime \prime S}$ $41^{\circ} 6^{\prime} 53.4$ ”W, 449 m a.s.l., 1 May 2013, A. M. Zanata, R. Burger, L. Oliveira \& R. Abreu.

Diagnosis. Pareiorhaphis lophia differs from all congeners in having two exclusive features: (1) a skin fold just posterior to each emergent tooth series of dentary formed by a single enlarged, flattened papilla, and (2) the midline of lower lip immediately behind the dentaries with small patch of distinct papillae arranged in a short median bump ( $v s$. papillae not projected in a bump). Moreover, the lower caudal peduncle also distinguishes $P$. lophia from all remaining Pareiorhaphis species (6.7-7.8 vs. 7.8-14.0\% SL), with the exception of $P$. proskynita. Furthermore, $P$. lophia can be distinguished from remaining congeners but $P$. bahianus, $P$. cerosus, $P$. eurycephalus, $P$. nudulus, $P$. parmula, $P$. steindachneri, and $P$. vestigipinnis by the lower number of dentary teeth (2038 vs. 42-120). Pareiorhaphis lophia can be distinguished from $P$. bahianus, $P$. cerosus, $P$. eurycephalus, $P$. parmula, and $P$. steindachneri by the usual absence of first dorsal-fin spinelet ( $v s$. spinelet present). The new species can be further distinguished from $P$. nudulus and $P$. vestigipinnis by the possession of an adipose fin ( $v s$. adipose fin absent) and the narrower caudal peduncle (4.1-5.3 vs. 5.5-8.7\% SL).

Description. Counts and measurements in Table 1. Small to medium-sized loricariid with standard length of measured specimens 45.5-82.1 mm SL. Head and body moderately depressed. Greatest body width at cleithrum, progressively tapering to end of caudal peduncle. Dorsal profile of body slightly convex, from snout tip to dorsal-fin origin and almost straight from that point to end of adipose fin, then slightly concave to caudal fin. Greatest body depth at dorsalfin origin. Least body depth at shallowest part of caudal peduncle. Trunk and caudal peduncle mostly oval in crosssection, flattened ventrally and more compressed caudally. Lateral-line canal in median series complete, pored tube visible from compound pterotic to caudal-fin base. Ventral 


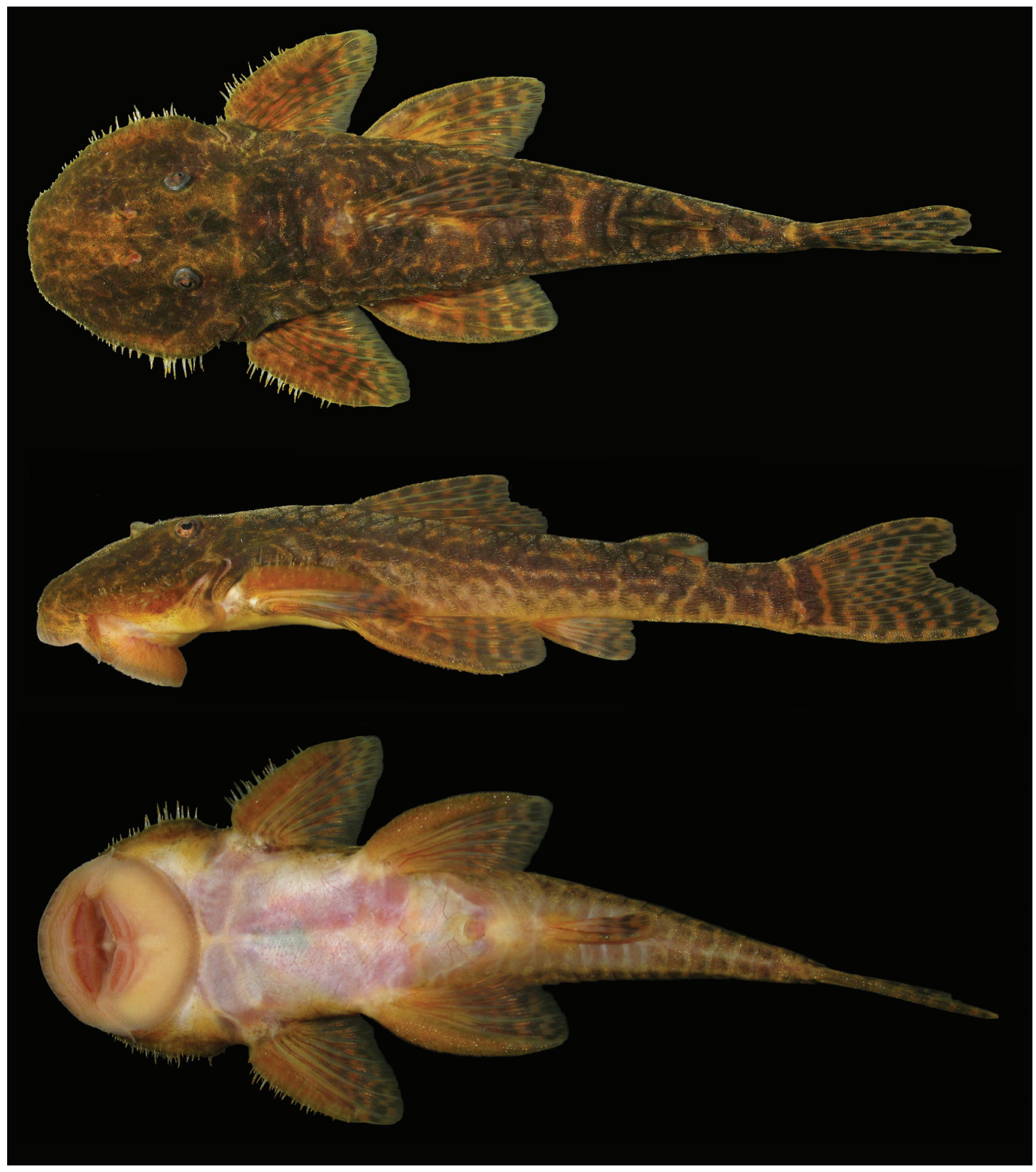

Fig. 1. Pareiorhaphis lophia, MCP 47711, holotype,76.9 mm SL, male, Brazil, Bahia State, Lençóis, rio Paraguaçu drainage,

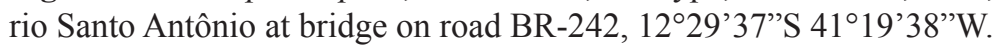

profile almost straight between snout tip and pelvic girdle, slightly elevating posteriorly along anal-fin base, almost straight along caudal peduncle. Dorsal surface of body covered by plates except for narrow naked area around dorsal-fin base. Predorsal plates arranged in three to four series of pairs in some specimens, or without any noticeable arrangement. Five lateral rows of dermal plates covering body, not forming keels; mid-dorsal and mid-ventral series of lateral plates incomplete, terminating four or five plates before caudal fin. Abdomen entirely devoid of plates. First 
anal-fin pterygiophore covered by skin. Lower surface of head and portion from pelvic-fin insertions to anal-fin origin completely naked, except by plated region around anal fin.

Head broad and moderately depressed. Outline of head round in dorsal view. Interorbital space straight or slightly concave. Three weakly elevated ridges between orbits and snout tip. Median ridge slightly more prominent. Snout convex in lateral profile; snout tip with rounded area of naked skin, devoid of odontodes. Adult males with welldeveloped soft fleshy lobes on lateral portion of head. Soft fleshy area ornamented with short hypertrophied odontodes, approximately perpendicular to body axis (Fig. 1). Eye small, dorsolaterally placed. Iris operculum small or absent in some specimens. Nares ovoid, slightly longer than wide, positioned much closer to anterior margin of orbit than to snout tip.

Oral disk circular. Lips moderately developed, occupying most of ventral surface of head. Upper lip narrow, bearing small rounded papillae. Lower lip wide but not reaching pectoral girdle. Lower lip densely covered by minute papillae. Papillae surrounded by small naked areas, decreasing in size towards edge. Patch of distinct papillae at midline of lower lip immediately behind dentaries, arranged in short median and forming a bump (Fig. 2). Posterior margin of lower lip fringed. Maxillary barbel short, mostly adnate to lower lip and with small free portion distally. Teeth series in both premaxillae and dentaries forming shallow arc with overall angle less than 180 degrees, with mesial ends slightly curved inwards. Teeth slender, asymmetrically bifid, medial cusp slightly curved inwards. Lateral cusp long and pointed, reaching half-length of medial cusp. Distinct skin fold posterior to each emergent tooth series of dentary formed by single enlarged, flattened papilla (Fig. 2).

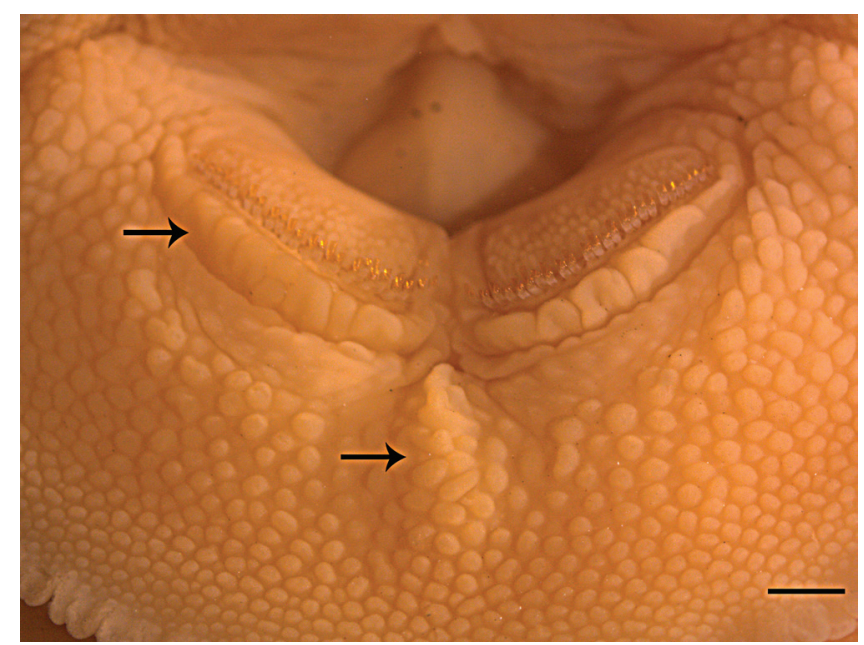

Fig. 2. Lower lip detail of Pareiorhaphis lophia, paratype, MCP $47712,71.1 \mathrm{~mm}$ SL. Scale bar $=1 \mathrm{~mm}$. Arrow on top indicates the flattened papilla and arrow on bottom indicates the bump.
Dorsal fin origin on vertical line through pelvic-fin origin. Dorsal fin short, reaching three plates behind its base terminus when adpressed. Nuchal plate exposed, not covered by skin. Dorsal-fin spinelet usually absent. Dorsal-fin locking mechanism non-functional. Dorsal-fin spine moderately flexible, followed by seven branched rays. Distal margin of dorsal fin straight. Adipose fin with well-ossified leading spine bearing odontodes. Adipose-fin membrane short or extended slightly beyond adipose-fin spine. Adipose fin preceded by two or three median azygous plates. Pectoral-fin origin situated more dorsally than pelvic-fin origin. Pectoral fin moderate in size, with curved and flattened unbranched ray, covered by minute odontodes in immature males and females. Adult males with first pectoral-fin spine very broad and straight, curved on its base; bearing straight and short hypertrophied odontodes on its entire surface; dorsal surface with discrete dermal flap along its entire length. Pectoral fin I,6; first and second branched rays distinctly longer than spine and subsequent branched rays decreasing gradually in size. Posterior margin of pectoral fin straight, surpassing pelvic-fin origin when adpressed. Pelvic fin i,5, not reaching or just reaching origin of anal fin when adpressed. Pelvic-fin unbranched ray depressed, covered with minute odontodes ventrally and laterally. Well-developed dermal flap on dorsal surface of pelvic-fin unbranched ray; flap of males distinctly higher near fin base, and extending to tip of ray in adult males; flap of females reduced or absent. Anal fin i,5. Caudal-fin posterior margin forked or slightly concave, asymmetrical; lower lobe longer than upper; 14 branched rays. Upper caudal-fin lobe with four and lower lobe with two or three plate-like procurrent rays. Posteriormost procurrent rays elongate. Hypural plate asymmetrical with lower lobe longer than upper. Total vertebral centra 28.

Color in alcohol. Ground color of dorsal surface of head and body light to dark brown; yellowish or whitish pale ventrally (Fig. 1). Cheeks, anterior margin of snout, area between nostrils and orbits, and compound pterotic covered with small, irregularly shaped, light or dark brown blotches. Soft fleshy skin on lateral portion of head well developed and whitish in adult males. Narrow transversal light brown bar extending through middle portion of supraoccipital. Dorsum and most of flank covered by irregularly closelyset darker brown blotches sometimes coalescing. Blotches usually arranged in five inconspicuous transverse saddles, situated between posterior margin of supraoccipital and origin of dorsal fin, behind dorsal-fin spine, posterior portion of dorsal-fin base, at preadipose area, and between adipose and caudal fins. Midlateral region of body with dark brown blotches contrasting with somewhat reticulate light areas. Ventral portion of head and abdomen either completely whitish or pale yellow. Ventral portion of caudal peduncle with numerous small dark blotches more conspicuous in 
Table 1. Morphometric and meristic data of the type series of Pareiorhaphis lophia. Values given as percents of standard length or head length. $\mathrm{H}=$ holotype, $\mathrm{n}=$ number of specimens, and $\mathrm{SD}=$ standard deviation.

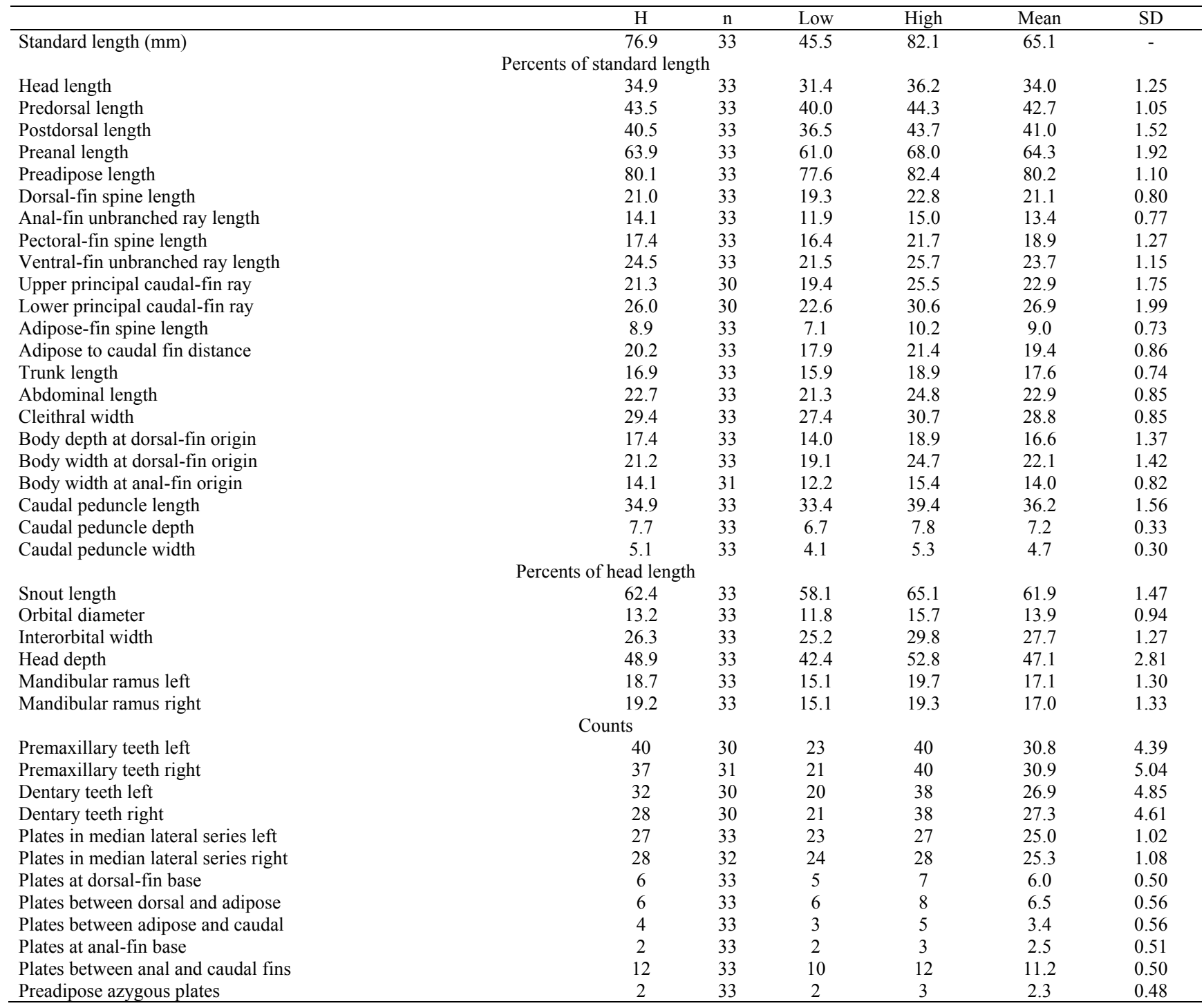

region after posterior margin of anal fin. First thickened rays of dorsal, pectoral, and pelvic fins light brown or grayish. Dorsal and caudal fin branched rays with 2-5 transverse irregular dark bars. Paired fins with diffuse blotches from middle to margin of fin, sometimes arranged in few irregular series. One or two dark brown blotches at adipose-fin spine.

Color in life. Color pattern of freshly collected specimens light brown to yellowish tan with small and irregular dark spots scattered on dorsal region of head and predorsal area (Fig. 3). Posterior region of body and flank with wide dark brown transversal saddles. Soft fleshy skin on lateral portion of head and first thickened rays of pectoral and pelvic fins yellowish. Markings on caudal fin conspicuous with narrow blotches irregularly arranged on unbranched and branched caudal-fin rays sometimes forming four or five dark brown narrow stripes. Iris golden.
Distribution. The new species is known from middle portion of the rio Paraguaçu and two tributaries of its upper portion (Fig. 4a). Extensive ichthyological collecting efforts through the main coastal rivers across Bahia in recent years failed to yield samples of Pareiorhaphis lophia from outside the rio Paraguaçu drainage, making it possible that the species is endemic to that river basin.

Common name. Acari, chupa-pedra.

Habitat and ecological notes. The rio Paraguaçu is a blackwater coastal river situated in northeastern Brazil, with headwaters on highlands of central Bahia State. The river stretch in Iaçu, at the period of sampling, was around $60 \mathrm{~m}$ wide with rocky platforms exposed on the river borders. The riparian vegetation is represented by a few trees restricted to the river border and the surrounding area is almost completely 


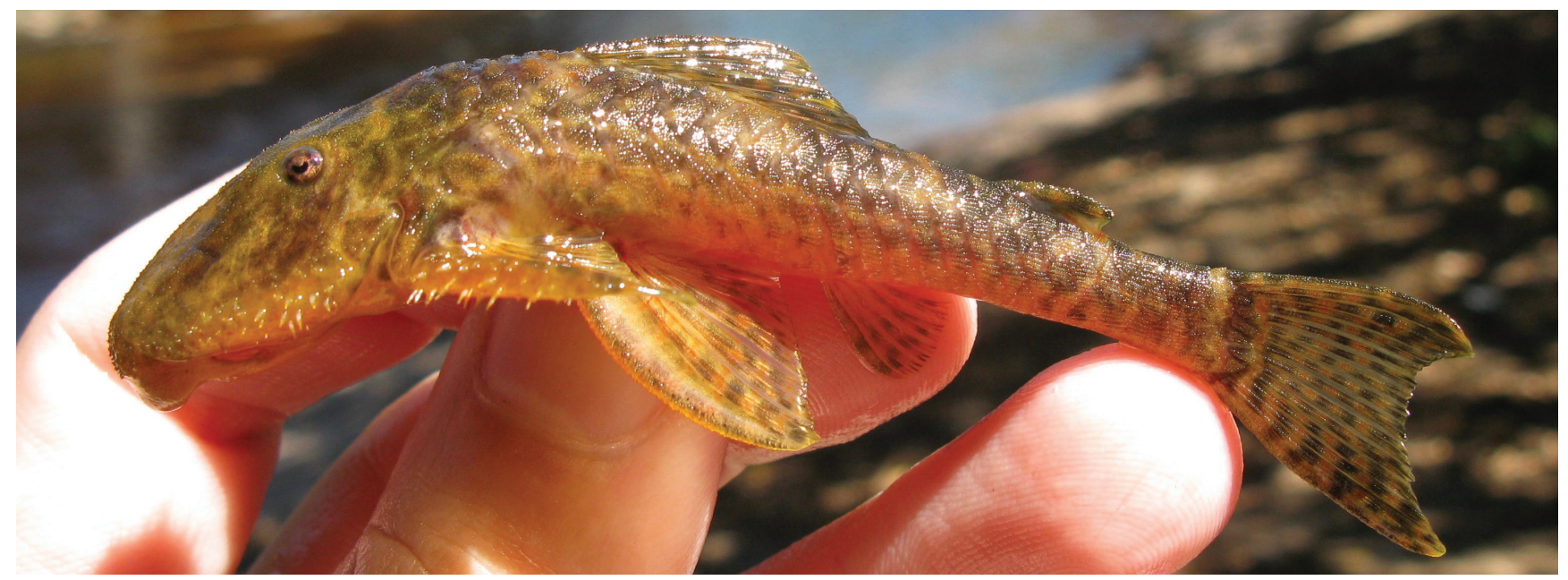

Fig. 3. Lateral view of Pareiorhaphis lophia, holotype, MCP 47711, $76.9 \mathrm{~mm}$ SL, photographed immediately after collection (left side of body). Photo by J. L. O. Birindelli.

anthropized mainly by cattle ranching. The specimens were collected at night, on the shallow rocky platforms and inside crevices. Data about the other location on the rio Paraguaçu, situated upstream Itaetê, are not available. The rio Santo Antônio, a blackwater tributary of the upper rio Paraguaçu, is around 20 meters wide and surrounded by riparian forest in the stretch sampled (Fig. 4b). Stretches of rapids and pools alternate, with rocks, loose stones, pebbles, and sand composing the substrate. At that sampling point, the specimens of Pareiorhaphis lophia were hidden among pebbles on the shallow rapids. In the rio Una, also a blackwater river, the new species was sampled on narrow stretches around $50 \mathrm{~cm}$ deep, just below a waterfall, with fast water current and rocky bottom. The specimens gathered at this locality were hidden in crevices or under large stones. The new species occurs syntopically with the loricariids Hypostomus chrysostiktos Birindelli, Zanata \& Lima and $H$. jaguar Zanata, Sardeiro \& Zawadzki.

Sexual dimorphism. The sexual dimorphism of Pareiorhaphis lophia is characterized mainly by the large soft fleshy lobes restricted to middle portion of the lateral margins of head that extends from anterior margin of nostrils to posterior margin of orbits of adult males. This soft area is ornamented by short hypertrophied odontodes. Odontodes also occur in females and juveniles, but are comparatively much smaller, while soft lobes are absent in females and juveniles. Also, adult males have the unbranched pectoral fin-ray strongly intumescent along its entire length with the dorsal, lateral and ventral faces ornamented with short hypertrophied odontodes, sometimes equal in size to those on head margin, that are absent in females. In addition, fully developed males have a narrow fleshy flap along the entire length of the dorsal margin of the pectoral-fin spine that is present in females but reduced. In adult males, the thickened first pelvic-fin unbranched ray have developed dermal flap along the entire dorsal surface and distinctly higher near fin base, while in females the dermal flap is reduced. Compared to males, females possess an enlarged, swollen urogenital opening, while males have a small and pointed urogenital papilla.

Comments. The absence of first dorsal-fin spinelet also diagnoses Pareiorhaphis lophia from most of the remaining congeners. However, variation in this feature was noted in the type series. The single specimen of the lot MCP 47712 (64.1 $\mathrm{mm} \mathrm{SL}$ ) has a reduced first dorsal-fin spinelet. Although the absence of dorsal fin-spinelet must be considered diagnostic to Pareiorhaphis lophia, the variation related to this feature deserves mention.

Etymology. The species name lophia is from the Greek $\Lambda$ oфi $\alpha$, meaning crest, ridge. In allusion to the presence of distinct bump on the lower lip, a diagnostic feature of the new species. A noun in apposition.

\section{Discussion}

The most distinctive feature of Pareiorhaphis lophia is the single narrow and transversally flattened papilla, just posterior to each dentary, which easily distinguishes $P$. lophia from all its congeners. Among the neoplecostomines, the distinctive papilla posterior to each dentary is similar to a series of papillae found in Neoplecostomus. However, the new species fits in the diagnosis of Pareiorhaphis proposed by Pereira et al. (2007) and can be further distinguished from all Neoplecostomus species by the absence of a thoracic shield of small dermal platelets located between the pectoral girdle 

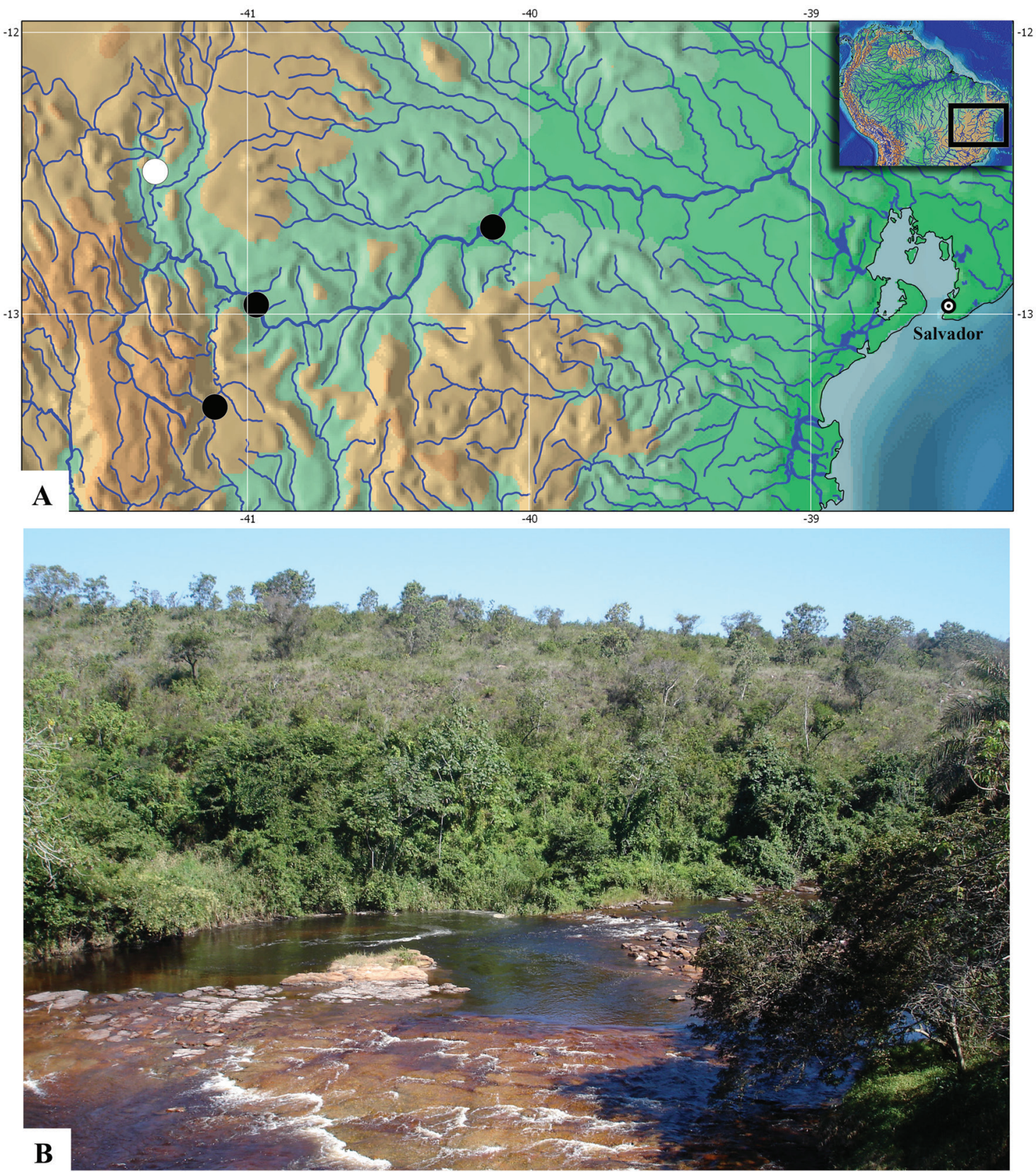

Fig. 4. Geographic distribution and river inhabited by Pareiorhaphis lophia: (a) map of rio Paraguaçu basin, Bahia State, northeastern Brazil, showing distribution of the new species (white symbol represents type locality), (b) type locality, Lençóis, rio Paraguaçu drainage, rio Santo Antônio.

and the pelvic-fin insertions, present in all Neoplecostomus species. In addition, $P$. lophia exhibits a single flattened papilla posterior to the dentaries (Fig. 2) whereas two or three series of large papillae are found in most species of Neoplecostomus. Neoplecostomus selenae also possess one or two irregular series of large flattened papillae, just posterior to the dentary (Zawadzki et al., 2008), however, P. lophia is readily distinguished from $N$. selenae by the presence of well-developed hypertrophied odontodes and soft fleshy skin on the lateral margin of head in adult males ( $v s$. absence in adult males of $N$. selenae). Furthermore, the new species is also distinct from all congeners in having a small patch of distinct papillae arranged in a short median and slightly more elevated bump (Fig. 2) at the midline of lower lip, immediately behind the dentaries (vs. papillae not elevated in a bump). This feature also occurs in the hypoptopomatine Hisonotus insperatus, which possesses a distinct median series of papillae at the midline of lower lip behind to the dentaries, arranged in a bump (Britski \& Garavello, 2003; Martins \& Langeani, 2012). Despite of these similar morphology, H. insperatus and $P$. lophia are relatively distant phylogenetically and these features are likely convergent. 
Among Pareiorhaphis species, P. bahianus described from Fazenda Almada, Ilhéus, is the geographically closest species to $P$. lophia. However, in addition to the feature related to the papillae on lower lip and absence of dorsal-fin spinelet in most specimens, the new species further differs from $P$. bahianus in having a smaller interorbital width and orbital diameter (25.2$29.8 v s .32 .1-39.0 \%$ HL and 11.8-15.7 vs. 15.8-18.8\% HL, respectively). With the description of Pareiorhaphis lophia, the genus Pareiorhaphis is now represented by two species in Bahia State and the new species represents the northernmost distribution record for the genus.

Comparative material. Material examined in addition to that listed by Pereira \& Reis (2002), Pereira \& Britto (2012) and Pereira et al. (2012): Pareiorhaphis proskynita. MNRJ 38561, 83.9 mm SL, holotype, Minas Gerais, rio Doce drainage, Catas Altas, ribeirão Caraça at Taboões, R. P. P. N. Santuário do Caraça, tributary to rio Piracicaba. MCP 46318, 20 paratypes, 1 c\&s, $69.2 \mathrm{~mm} \mathrm{SL}$, same locality as the holotype. Pareiorhaphis ruschii. MCP 46640, 84.7 mm SL, holotype, Espírito Santo, Santa Teresa, córrego Lombardia ca. $1 \mathrm{~km}$ NE of the Reserva Biológica Augusto Ruschi, tributary to rio Piraquê-Açu. MCP 44807, 25 paratypes, 2 c\&s 53.1-61.8 mm SL, collected with the holotype.

\section{Acknowledgments}

We thank C. P. Oliveira, D. França, J. L. Birindelli, M. P. Geraldes, O. T. Oyakawa, P. Moura, P. Camelier, and R. Burger for help in the fieldwork. The fisherman João Junior Silva da Conceição was particularly helpful in the acquisition of adult specimens. Priscila Camelier provided the map for Fig. $4 \mathrm{a}$ and Pablo Lehmann prepared Fig. 1. For the loan of specimens and other assistance we thank C. Lucena (MCP) and O. Oyakawa (MZUSP). Recent material was acquired in field expeditions funded by All Catfish Species Inventory (NSF DEB-0315963), during an expedition to Paraguaçu and Itapicuru rivers (EPI), in July 2005, and CNPq (\# 133917/2010-0) on other occasions. EHLP is partially supported by a postdoctoral fellowship from CNPq (Proc. 151624/2009-7). Permission for collecting specimens was granted by IBAMA \# 13754-1.

\section{Literature Cited}

Birindelli, J. L., A. M. Zanata \& F. C. T. Lima. 2007. Hypostomus chrysostiktos, a new species of armored catfish (Siluriformes: Loricariidae) from rio Paraguaçu, Bahia State, Brazil. Neotropical Ichthyology, 5: 271-278.
Britski, H. A. \& J. C. Garavello. 2003. Hisonotus insperatus: new species, from the upper rio Paraná basin (Pisces: Ostariophysi: Loricariidae). Copeia, 2003: 588-593.

Carvalho, M. \& F. A. Bockmann. 2007. Família Loricariidae: Hypostominae. Pp. 68-72. In: Buckup, P. A., N. A. Menezes \& M. S. Ghazzi (Eds.). Catálogo das espécies de peixes de água doce do Brasil. Série livros 23, Museu Nacional, Rio de Janeiro.

Martins, F. O. \& F. Langeani. 2012. Hisonotus piracanjuba, a new species of Hypoptopomatinae (Siluriformes: Loricariidae) from the rio Paranaíba, upper rio Paraná system, central Brazil. Ichthyological Exploration of Freshwaters, 23: 29-36.

Pereira, E. H. L. 2005. Resurrection of Pareiorhaphis Miranda Ribeiro, 1918 (Teleostei: Siluriformes: Loricariidae), and description of a new species from the rio Iguaçu basin, Brazil. Neotropical Ichthyology, 3: 271-276.

Pereira, E. H. L. \& R. E. Reis. 2002. Revision of the loricariid genera Hemipsilichthys and Isbrueckerichthys (Teleostei: Siluriformes), with descriptions of five new species of Hemipsilichthys. Ichthyological Exploration of Freshwaters, 13: 97-146.

Pereira, E. H. L., F. Vieira \& R. E. Reis. 2007. A new species of sexually dimorphic Pareiorhaphis Miranda Ribeiro, 1918 (Siluriformes: Loricariidae) from the rio Doce basin, Brazil Neotropical Ichthyology, 5: 443-448.

Pereira, E. H. L., F. Vieira \& R. E. Reis. 2010. Pareiorhaphis scutula, a new species of neoplecostomine catfish (Siluriformes: Loricariidae) from the upper rio Doce basin, Southeastern Brazil. Neotropical Ichthyology, 8: 33-38.

Pereira, E. H. L. \& M. R. Britto. 2012. A new distinctively colored catfish of the genus Pareiorhaphis (Siluriformes: Loricariidae) from the rio Doce basin, Brazil. Copeia, 2012: 519-526.

Pereira, E. H. L., P. A. Lehmann \& R. E. Reis. 2012. A new species of neoplecostomine catfish Pareiorhaphis (Siluriformes: Loricariidae) from the coastal basins of Espírito Santo, eastern Brazil. Neotropical Ichthyology, 10: 539-546.

Schaefer, S. A. 1997. The neotropical cascudinhos: systematics and biogeography of the Otocinclus catfishes (Siluriformes: Loricariidae). Proceedings of the Academy of Natural Sciences of Philadelphia, 148: 1-120.

Taylor, W. R. \& G. C. Van Dyke. 1985. Revised procedures for staining and clearing small fishes and other vertebrates for bone and cartilage study. Cybium, 9: 107-119.

Zawadzki, C. H., C. S. Pavanelli \& F. Langeani. 2008. Neoplecostomus (Teleostei: Loricariidae) from the upper rio Paraná basin, Brazil, with description of three new species. Zootaxa, 1757: 31-48.

Zanata, A. M., B. Sardeiro \& C. H. Zawadzki. 2013. A new dark-dotted species of Hypostomus Lacépède (Siluriformes: Loricariidae) from rio Paraguaçu, Bahia State, Brazil. Neotropical Ichthyology, 11: 247-256.

Submitted August 20, 2013 Accepted December 16, 2013 by Marcelo Britto Published march 31, 2014 